\title{
Primary hyperaldosteronism: case presentation
}

\author{
Rodica Petris1, Constantin Dumitrache1, Sorin Paun2, Roxana Ganescu2, Mara Carsote1, Catalina Poiana1, Diana Paun1
}

\author{
1.National Institute of Endocrinology C.I. Parhon Bucharest \\ 2. Clinical Emergency Hospital Bucharest
}

\section{Introduction}

Hypertension, increased aldosterone excretion, suppressed plasma renin activity charecterize the syndrome of primary aldosteronism. We should consider testing for primary aldosteronism in the presence of hyperension and hypokalemia, resistant hypertension, adrenal incidentaloma, onset of hypertension at a young age $(<20 \mathrm{y})$, severe hypertension and whenever considering secondary hypertension.

\section{Case presentation}

We presented the case of a 38 years old woman who was admitted in the National Institute of Endocrinology C.I.Parhon Bucharest for the evaluation of high blood pressure. She has high blood pressure for 10 years (maximum value 190/100 $\mathrm{mm} \mathrm{Hg}$ ) and she is on $\beta$ blocker and angiotensin II receptor blockers. She has no other medical history and her blood pressure is still $150 / 80 \mathrm{~mm} \mathrm{Hg}$ on the antihypertensive drugs. She has heredocolateral antecedents of high blood pressure (her mother has high blood pressure from the age of 56 years). After she has stopped for 4 weeks the antihypertensive drugs, we detected hypopotasemia ( $\mathrm{K}: 2,9 \mathrm{nmol} / \mathrm{L})$, normal serum natrium, and normal biochemia but high levels of serum aldosterone $(121 \mathrm{ng} / \mathrm{dl})$ and low levels of serum renin $(2 \mu \mathrm{Ul} / \mathrm{ml})$ with plasma metanephrines and normetanephrines in the upper normal range and normal plasma cortisol with good response after $1 \mathrm{mg}$ overnight dexamethasone suprression test. An adrenal computed tomography has been performed and we discovered a left adrenal mass of $1,2 / 0,9 \mathrm{~cm}$. We have replaced the $\beta$ blocker with Spironolactona ( $200 \mathrm{mg} / \mathrm{day})$ and Aspacardin and on these medications she has high normal blood pressure and normal potassemia. The patient was transferred to the surgery where they performed laparoscopic adrenalectomy. Two weeks after surgery she has normal blood pressure and normal natremia and potassemia without medications.

Mean value of blood parameters

\begin{tabular}{|l|c|c|c|c|}
\hline & $\begin{array}{c}\text { Serum } \\
\text { Aldosterone } \\
\text { (N: 1,76-23,2 } \mathrm{ng} / \mathrm{dl})\end{array}$ & $\begin{array}{c}\text { Serum Renin } \\
\text { (N: 2,8-39,9 } \mathrm{uU} / \mathrm{ml})\end{array}$ & $\begin{array}{c}\text { Natrium } \\
\text { (N: 137-145 mmoli/) }\end{array}$ & $\begin{array}{c}\text { Serum } \\
\text { Potassium } \\
\text { (N: 3,5-5,1 mmoli/l) }\end{array}$ \\
\hline Before surgery & 121 & 2 & 138 & 2,9 \\
\hline After surgery & 19 & 10 & 140 & 4,1 \\
\hline
\end{tabular}

\section{CT: adrenal adenoma}

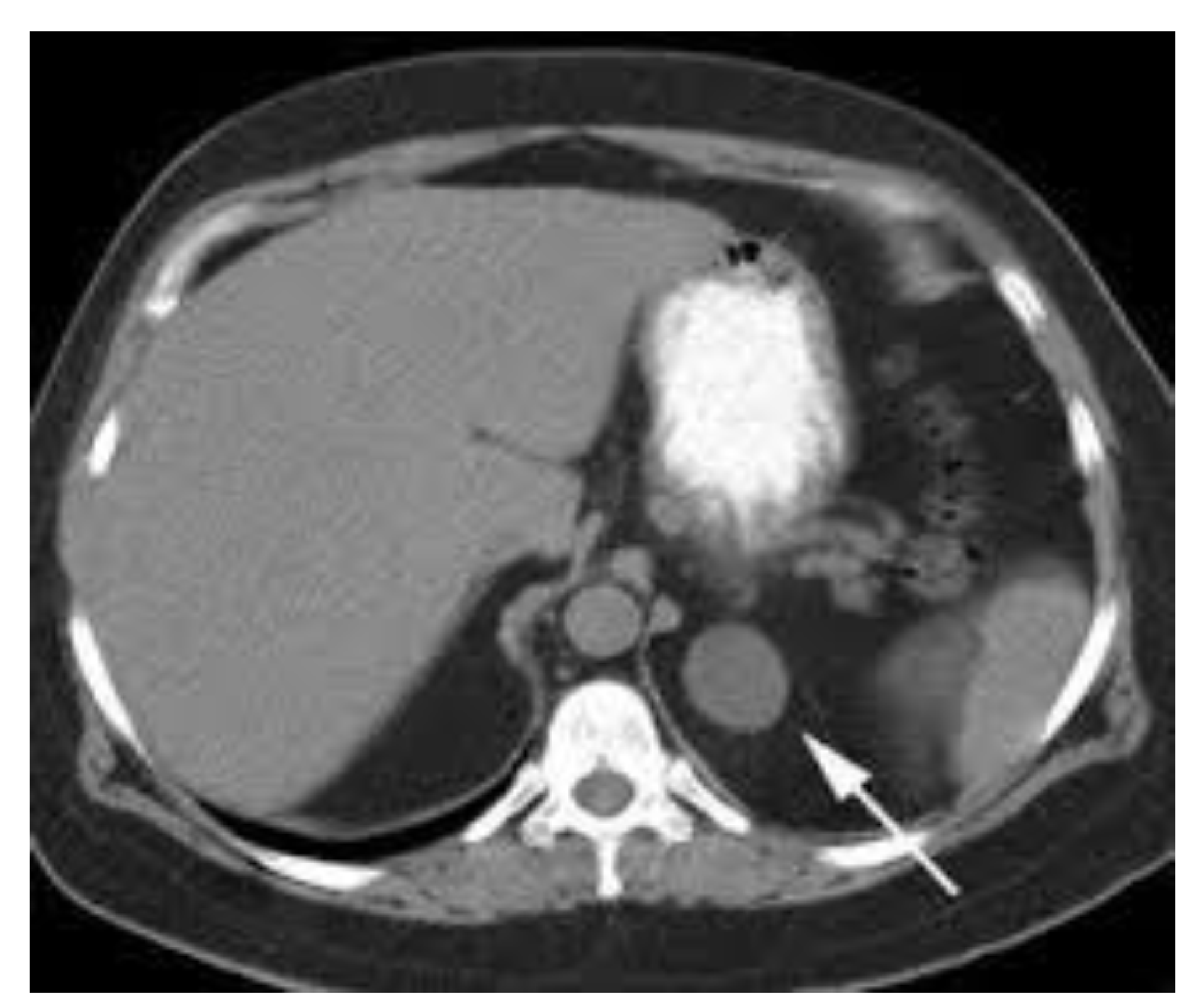

\section{Conclusions}

We presented the case of o woman with primary hyperaldosteronism and although she has high blood pressure for 10 years and we have not expected that it would be entiraly coreccted after surgery, the patient did not need any antihypertensive drugs after surgery. Average long-term cure rates of hypertension after unilateral adrenalectomy range from $30 \%$ to $60 \%$. Persistent hypertension following adrenalectomy is correlated with the duration of hypertension, older age, use of more than two antihypertensive drugs, increased serum creatinine level, having more than one first degree relative with hypertension [1,2]. The current literature does not identify a gold standard confirmatory test for primary hyperaldosteronism. A patient with a positive aldosterone-renin ratio should undergo testing by any of four confirmatory test (oral sodium loading, saline infusion, fludrocortisone suppresion, captopril challenge) [3]. Our patient had the Captopril challenge test but plasma aldosterone did not suppress (2 $\mathrm{h}$ after challenge plasma aldosterone was $110 \mathrm{ng} / \mathrm{ml}$ ). Because laparoscopic adrenalectomy is the treatment of choise for patients with documented unilateral hyperaldosteronism (adenoma or hyperplasia) the distinction between unilateral and bilateral adrenal disease sholud be made by adrenal venous sampling. CT has its limitations (nonfunctioning unilateral adrenal macroadenomas are not uncommon, hyperplasia may appear normal on CT etc) [4]. Our patient did not have adrenal venous sampling (we don't do it in our center). During the first two weeks after surgery , a generous sodium diet should be recommended to avoid the hyperkalemia that can develop from hypoaldosteronism due to chronic contralateral adrenal gland suppression. In rare instances, temporary fludrocortisone therapy may be required. Blood pressure typically normalizes or shows maximal improvement in 1-6 months after unilateral adrenalectomy but can continue to fall for up to 1 year in some patients [5]. Our patient did normalize her blood pressure practically after 1 month.

\section{References}

1.. Meyer A, Brabant G, Behrend M 2005 Long-term follow-up after adrenalectomy for primary aldosteronism. World J Surg 29:155-159

2. SawkaAM,Young WF, Thompson GB, Grant CS, Farley DR, Leibson C, van Heerden JA 2001 Primary aldosteronism: factors associated with normalization of blood pressure after surgery. Ann Intern Med 135:258-261

3. Giacchetti G, Ronconi V, Lucarelli G, Boscaro M, Mantero F 2006 Analysis of screening and confirmatory tests in the diagnosis of primary aldosteronism: need for a standardized protocol. J Hypertens 24:737-745

4. Kloos RT, Gross MD, Francis IR, Korobkin M, Shapiro B 1995 Incidentally discovered adrenal masses. Endocr Rev 16:460-484

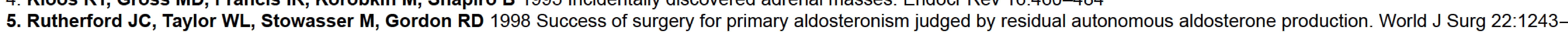
1245 